\title{
Durkheim on Power and Holiness
}

\author{
By BERNDT GUSTAFSSON
}

Emile Durkheim has as nobody else brought together power and holiness as pre-requisites for each other. Power was holiness, and holiness was power.

Power should here be understood as the ability to act collectively or on the behalf of the collective.1 Power comes-and not only for Durkheimfrom out of the collective. The collective is, however, for Durkheim, holy, all imperative and uncompromising, unapproachable and incorruptible. The holy, "le sacré", is thus always of social origin and can only be explained sociologically. ${ }^{2}$

Durkheim may well call the holy for a religious category, but the religious phenomena are in themselves products direct from collective feelings, phenomena, through which the collective expresses itself in holiness and thereby continually celebrates and strengthens itself.

He can conceive of collectively shared ideas and of collectively performed rites, which are not religious, although in all points resembles religious ones. But they are then not as necessary, not as obligatory for the collective as the religious ones. It is the character of compulsory necessity, which turns the religious phenomena into religious phenomena. Holy is that which is obligatory, profane is that which is voluntary. ${ }^{3}$ There is always something of compulsion and obligation in the holy.

\section{Holiness and the mystery of power}

Religion, the domain of holiness, is a representation of the collective spirit, maintained Durkheim again and again. ${ }^{4}$ It does not however mean that the

${ }^{1}$ Hannah Arendt, On violence, Sthlm I970, p. 42.

2 E. Durkheim, fournal sociologique, Paris 1969, p. 165 (1897-1898).

${ }^{3}$ Durkheim never discussed the Free-Churches. He started, which is well-known, first of all from Central Australian tribes.

${ }^{4}$ Durkheim, Fournal sociologique, p. I62 (1897-r 898); E. Durkheim, The elementary forms of the religious life (I9I2), New York I96I, p. I $5 \mathrm{ff}$. 
feature of mystery in religion disappears, but on the contrary, that this is a pre-requisite for the collective spirit's religious representation. The collective's representation in holiness is not the product of reasoned consideration on the behalf of the individual. Society has its method of expressing itself and its method of thinking. It has its passion, its customs, its needs, which are not the private individual's, but which set their stamp on everything which the collective imagines for itself. "It is then not surprising, that we as individuals cannot rediscover ourselves in these ideas. They are not ours, they do not express us. Thus it is, that they have an air of mystery, which troubles us (italics ours). That mystery, however, is not even to be found in the object, which these ideas represent. It is entirely dependent on our ignorance." It was a provisional mystery, as in all other areas, where science had not yet made sufficient advances. "When we find laws for that collective formation of ideas, so those strange representations will lose their character of strangeness."'1

Holiness should therefore diverge from power, thought Durkheim, to that extent that science, sociology, liberated society's morality from its mystery. But science was then only an expression for the division of labour, and when the unmysterious, professional, society morality came in the place of religion (and with it, holiness turned away). Sociology was a link in the transformation of society. The sociologists, least of all, today are so certain of their science's liberating mission. Sociological metaphors have become part of the modern myths and thus carried holiness further. ${ }^{2}$

Mystery belongs together with holiness. For Durkheim, the holiness in the power of the collective comes also from the anonymity in that irresistable strength. It is for that reason, that a further representation must be realized, as a totem or a godfigure, towards which cult and rite direct themselves.

At the same time, however, no society can live without individual awareness. It is only by means of this, that the collective can be realized. "If, therefore, religious strength, in so far as it may be understood to be incorporated in the totemic emblem, is thought to be outside the individual and equipped

\footnotetext{
${ }^{1}$ Durkheim, Fournal, p. I6z.

2 S. T. Bruyn, The human perspective in sociology, Englewood-Cliffs, New Jersey I966, p. 140 .
} 
with a sort of transcendence over the individual, so it is realized nevertheless, like the clan whose symbol it is, only in and through the individual, in this sense it is inherent in him and by necessity he represents it as such. He feels it present and active within himself, for it is that, which raises him to a higher life." Nevertheless, the individual participates only indirectly as an individual. Strength is not inherent in him, but comes to him from without. ${ }^{1}$

Durkheim's views on holiness as the collective anonymous power's mysterious expression are not contested by Victor W. Turner's interpretation of holiness as an expression for antistructure and powerlessness. ${ }^{2}$ Holiness flows even here out of the community but unstructuralised and thereby total. The new idea, which Turner, on the other hand, has indicated, is how the collective in its structures where power and status always receive an unequal distribution, becomes unholy, secular, professionally differentiated and individualised. Every initiation rite-even a simple one, such as the handing over of a citizen's book at the age of majority, a previously not unusual, modern, Swedish secular ritual-concludes notwithstanding, socialisation to the collective, strengthens the community and its mystery.

\section{Holiness shall diverge from power}

In his theory on the division of labour, Durkheim has an interpretation of how holiness, nevertheless, has diverged from power, in pace, with the division of power, the transition from mechanical (one for all, all for one) solidarity to organic solidarity (every limb in its function, all organically working together). It is, however, first with the industrial society, that power and holiness diverge, and Durkheim has to seek a new source for society morality and loyalty to power.

Even in Antiquity-and later in the Middle Ages-holiness for Durkheim, was an expression for the collective, its celebration of itself and its acknowledgement of itself. Certainly a private sphere, the household, asserted itself, as distinct from the city state, the police or from "res publica", but even the house-hold, the family, was a collective, with its hearth and its holiness. This little collective (usually a large family) rested, what is more,

${ }^{1}$ Durkheim, The elementary forms, p. 239.

2 V. W. Turner, The ritual process, London r 969 , p. 94. 
in the larger, the public collective and received from it its right and its morality. 1

Marriage and family survive-in spite of the opposite tendency in early Christianity-to a large extent still as a holy collective, although a shrinking one, increasingly deprived of power, holiness, sanctity, indissolubility and mysterious intimacy. Even if the growth of state and public life took place at the cost of the family's private sphere, the holiness or "patria potestas" of the hearth was never lost thus. A gulf between the household's private world and that of politics was secured, even in the Middle Ages.

On the development between the life of the Central Australian tribes and the industrial division of labour, Durkheim's output gives only smaller accounts. Certain points ought, however, to be clear. Early Christianity did indeed deny public power and holiness, which point is made clear by the well known passage in Tertullianus: "Nec ulla magis res aliena quam publica" (nothing is more alien to us than public life). ${ }^{2}$ Here, holiness stood in sharpest contrast to public office. A good deed--Hannah Arendt points out-lost its goodness according to primitive Christianity, if it became known and public. Goodness was done for its own sake. Holiness flowed out of itself. 3

When the Roman church became a substitute for Roman citizenship and thereby for participation in public holiness, religious life with its festivals thus became the public sphere, while the ancient private sphere had its counterpart in the secular area of feudalism. The struggle of "sacerdotium" and "imperium" became a struggle between public holiness and secular limitation. Holiness was still tied to the public sphere and the monarchy represented God as much as it did the collective, where it had yielded to the church, but it received its holiness more from the church and God than from the collective, which had already been limited. First with the national state could the collective again be thought of as conferring holiness. At the same time, however, the secular political sphere grew, already deprived of its holiness, professional and disunited.

${ }^{1}$ Durkheim, Foumal, p. 227, 247.

a Tertullian, apol., 38 . Even against the family as a collective the early Christianity maintained the individuality, J. Gaudemet, "Familie", Reallexikon für Antike und Christentum, 5 I, 1967, p. 35 I.

${ }^{3}$ Hannah Arendt, The human condition, Chicago I958, p. 74. 
With modern state doctrine, from natural rights, and with the growth of politics as bureaucracy and profession, burst, however, not only holiness, but also the collective. Individualism grew with the professional administrative state. ${ }^{1}$ And without the collective, there could be no holiness.

Every absolutist state still needs, according to Durkheim, a holiness of God, its power as an emanation of divine power. ${ }^{2}$ History can repeat itself. The division of labour, however, sets in and advances, specialising and desacralising.

Where holiness and power have diverged, even traditions and religious conceptions "serve as reins on the strongest governments". Even if the basis for morality is, of necessity, now another, because it always coincides with the social order, which itself has changed, so Durkheim still reckons with counterpressures, which moderate and limit the state in modern times. ${ }^{3}$

Society's morality should now instead-besides the organic solidarity within the industrial division of labour-come from the trade unions, and professional ethics. That professional ethics might be threatened by the bureaucratic process, which they partly arose from, never occurred to Durkheim, something which has been described as unforgivable negligence on the part of Durkheim. ${ }^{4}$ Certainly moral weakness, anomie, still prevailed in the industrial society, when the old holy morality collapsed, 5 but Durkheim looked forward.

\section{The eirs of holiness}

Above all, Durkheim thought of religion as society's moral basis in the more developed society, as being replaced by groups and associations, professional organisations and trade unions. ${ }^{6}$ These to a certain extent can probably be said to inherit the holiness of the old collective, representing

\footnotetext{
1 Durkheim, Fournal, p. 227.

2 Durkheim, Fournal, p. $27 \mathrm{I}$.

3 Durkheim, Fournal, p. 246.

4 C. P. Wolf, "The Durkheim thesis: occupational groups and moral integration", Fournal for the Scientific Study of Religion, 9, 1970, p. 29.

${ }^{5}$ E. Durkheim, Le suicide, Paris 1897.

${ }^{6}$ Wolf, p. 24.
} 
the collective as they do, although their power is not unlimited, even if they do strive, after participation in the power of the state. ${ }^{1}$ Thus their holiness is limited. Unity can also be found nonetheless, in an industrial society, when it makes an appeal to all. As soon as unity comes to being in a society, the holy things, les choses sacrées, are there. They are things, whose representation society itself brings about, collective authority, traditions, common feelings, feelings, which relate to the general interest. ${ }^{2}$ As far as holiness is concerned, being sacré, there exists therefore, according to Durkheim, no actual difference between a Christian community, who celebrate events from the story of Christ, or for example, a meeting of citizens, who celebrate a new law or a big event in the nation's life, merely that unity exists there ${ }^{3}$ The first of May is a real festival day for those groups, who find a united interest expressed in that tradition. National saints or saints within movements with a large collective closeness are des choses sacrées. ${ }^{4}$

Profane things, on the other hand, are those, where each one of us, with empirical data, works out reality. Those ideas, which we then work with, are entirely "naked individual impressions", without that prestige that les choses sacrées have. ${ }^{5}$

Durkheim was not an evolutionist. Society can go from one space to another, go forwards and backwards. Power as holiness and holiness as power is to be found, therefore, even in industrially developed lands, as soon as collective forces come into play, but the counterbalances against the holiness of the state were many for Durkheim and professionalisation long advanced. Holiness could move over to other collective forces, but also move back to the state, if that became an expression for strong collectivity.

\section{The "holiness" of politics}

Durkheim came, in his eagerness to distinguish sociology as a science free from valuation from socialism as an ideology full of valuation ${ }^{6}$ to express

\footnotetext{
${ }^{1}$ R. D. Herrman, "Some remarks on public life", Diogenes, 69, r970, p. 37.

a Durkheim, The elementary forms, p. 37.

$3 \mathrm{ib}$.

4 W. L. Warner, The living and the dead, New Haven 1959, p. ro7.

s Durkheim, Fournal, p. I62.

- A. W. Gouldner, The coming crisis of Western sociology, London I971, p. 136.
} 
the common feeling among the pre-war bourgeoisie for what is useful. Morality was that which furthered social solidarity. ${ }^{1}$ In this lies a limitation, possibly, for the whole of Durkheim's perspective.

An entirely different judgement of state power was to be found in Marx: the state as the concern of everyone. Private life and individualism were unworthy aspirations. ${ }^{2}$ Holiness in the state was conspicuous for Marx, granted that the state would disappear in that politics and public affairs would become everything for all and everything in all. With later Marxism, power has again received holiness. The collective life-forms are holy, the private structures alienation, unreality.

Durkheim still lived in the liberal epoch, with its counterposition of public life and private life. Above all, career and family were nonpublic spheres. Society development has, nevertheless, caused the public sector to expand into these areas. Choice of career and the labour market are more and more controlled by the public sector. Even the family is guided more and more by the public sector, through the mass-media, direction of consumption and other things. There is, according to some, a risk that the family is becoming "the prisoner of society". "The private sector is regarded more and more as stained, dirty, only the public sector is holy, pure.

In later times it is maintained from different quarters, that the myth, the mysterious offering, and thereby also holiness still lives in politics. Severyn T. Bruyn has pointed to how myths continually generate from out of political life, from out of the lives of the people and the nation. The foundation for the myth is not thought, but feeling. Myth unites where reality differentiates. The political myth, however, is created more and more rationally. The earlier myth about the divine right of kings has a long inception, but later political myths cannot be understood in the same way. Thomas Hobbes was one of the first modern destroyers and creators of political myths. He participated in the breaking down of the myth of the kingdom as sacred, but replaced it with his rootmetaphor Leviathan. Hobbes' conception of humanity as a concluding contract to protect itself

\footnotetext{
${ }^{1}$ Gouldner, p. I23.

2 Herrmann, p. 32.

3 Herrmann, p. 37

4 Bruyn, p. 137.
} 
against its own cruel barbarity gained a mystic character. That which Rousseau later symbolised as "the noble savage" (against Hobbes) became a central political myth for western humanity. His theoretical explanation of the political order in terms of "the universal will", which regarded society as functioning, metaphorically as an individual, still represents a change in the history of the political myth, with a considerable effect on political life.

Even the political theory on democracy moves in today's society towards the guise of a myth, in so much as it captures people's passions and respect, in that they identify society or themselves with democracy or believe that their especial type of democracy is right for all people in all times, is "holy", the only right one. The more intensively this conception is grasped, the less it becomes a theoretical model, and the more it gains the genuine character of myth.

Bruyn motivates his examination of the myth as invading the political structure from outside the key position, which science has received in the structure of modern society, otherwise in accordance with Durkheim's prediction. Science has gained increasingly the position of secular authority, the position, which at one time was held by other institutions, like the church, and until recently the state. "Holiness" still follows society as a basic category and the connection with power still survives.

All social theory must have some central, leading conception, and thus, this produces symbolism, which unites the different parts of theory, and at the same time, unites people's feelings and interests. "As soon as a basic idea about people in society becomes a part of people's personal lives, it gains the symbolic attribute of the myth."1

In order to explain humanity and society there exist many metaphors and models, which are not questioned: "the structure of society", "the system of society", "structures". The metaphors create new views and a new spirit of understanding through illuminating a subject and leading to rational understanding. Models also function on the rational level and can be the object of criticism and empirical study, in their capacity of deliberate attempts to explain reality. The myths, on the other hand,

1 Bruyn, p. ז4 1 . 
are developed more slowly. They originate from people's feelings and conceptions of faith and become real to that extent in which they are shared collectively. That was approximately Durkheim's view of religion. Bruyn's demand for the demythologising of politics goes further than Durkheim's sociological explanation of religion.

Murray Edelman has also described how public life develops its own "holiness", when it no longer has religion as its collective representation. ${ }^{1}$ Political life has its rituals. General elections are only to a lesser extent a participation in policy formation. Like all rituals, in early as well as in modern societies, the election draws attention to common links and to the meaning and reasonability of accepting the public policy being carried out. The election has a vital function through the united idea that the people have control over government policies by the election. Or as a psychiatrist has put it: "There is possibly no other sphere, though perhaps that of religion, where the average citizen is more convinced of the logicality, the defensibility and complete rationality of his decision."'2

The election is a symbolical expression of solidarity. Certainly there are rational symbols of reference in politics, but it overflows also with condensation symbols, memories of past greatness or inferiority, promises of future justice, dramatic leads and the constant spreading of evocative and combining myths. "It is no chance that all totalitarian states engage their populations intensively and almost continuously in discussions of public affairs." ${ }_{3}$

Even the most democratic institutions are to great extent symbolic and expressive in their function, maintains Edelman. It is far too simple to think of a political system as an instrument, which more or less exactly gives the individual what he wants. The question of what a person is, not to mention what he wants, is partly a product of the political system and in turn conditions the system. The nature of humanity and the functioning of the system are parts of one and the same process. The expressive and symbolic functions of politics are therefore ever central, necessary

${ }^{1} \mathrm{M}$. Edelman, The symbolic uses of politics, Urbana 1964.

2 C. W. Wahl, "The relation between primary and secondary identifications", American voting behavior, ed. by E. Burdick and A. J. Brodbeck, 1959, p. 263.

${ }^{3}$ Edelman, p. 9. 
for social stability. It does not mean that the elites deliberately create political myths and rituals to serve their purpose, in the same way as the people, whom Durkheim studied, did not deliberately form religious conceptions and rites to express their collective unity. It is a question of collective role-taking, not a deceit.

Symbolism lies in that people read their own interpretations into situations, which are unclear and provocative. People cannot endure ambiguous and complex situations and reply therefore with symbols, which oversimplify. An emotional engagement in a unified symbol calms and purifies.

The administrative systems themselves-with their professional bureaucrats - dramatise the contrasts in society in order to create unity. They mirror the heterogeneity in economic and social interests in order to make them meet and bridge them over. They give solidarity and express solidarity over all adversities.

The political struggle has something of the "holy" drama about it. The leaders' dramaturgic struggle with public problems makes the world comprehensible and gives the promise of the collective and unified carrying out of the desired contributions. He collects the masses, who are uncertain, lonely and confused, in a united action.

The emotional heat, apparent or concealed in political argumentation and in the reactions to it, give a feeling of the reality of the struggle, the importance of the contributions, the captivating quality in the great drama of state. By emotionally participating in this drama, the individual retains a medium by which to express himself as one of the many. It is a rite, which helps the individual, in action, to express his own interest in politics as "a symbol for the whole" (Lasswell). This has still an overindividual character of reality. Power, as a mysterious and anonymous strength, still comes from the many, from society as a collective, and the play continues to bestow on the participants, something of collective greatness and stature. There is something obligatory in it all, something of compulsion. The means of expression are different, "holiness" is different, but not entirely gone. With the collectivism of mass society, the "holiness" of politics has been strengthened rather.

The assertion "everything is political" can then be understood in this way: it is we, our group, our collective, "the people", who are everything. 
For Durkheim, the Central Australian tribes' "everything is religion" also meant that "it is we, our collective, who are everything". Just as, at one time, the private individual became justified and sanctified through religion, by the "everything is political" marxism, he becomes so through politics. Holiness, however, still comes, according to Durkheim's observation, from ourselves, and politics then becomes humanity's justification and canonisation of itself. Durkheim's linking of power and holiness can intimate a thought structure, which does not entirely belong to the past. 